\title{
Bat community species richness and composition in a restinga protected area in Southeastern Brazil
}

\author{
Oprea, M. ${ }^{\mathrm{a}, \mathrm{b} *}$, Esbérard, CEL. ${ }^{\mathrm{c}}$, Vieira, TB. ${ }^{\mathrm{a}}$, Mendes, $P^{\mathrm{a}}{ }^{\mathrm{a}}$ \\ Pimenta, VT. ${ }^{\mathrm{a}}$, Brito, $D{ }^{\mathrm{d}}{ }^{\mathrm{e}}$ and Ditchfield, $A D .^{\mathrm{a}}$ \\ a'Laboratório de Estudos de Quirópteros, Departamento de Ciências Biológicas, \\ Universidade Federal do Espírito Santo - UFES, \\ Av. Marechal Campos, 1468, CEP 29040-090, Vitória, ES, Brazil \\ ${ }^{b}$ Division of Mammals, MRC 108, National Museum of Natural History, \\ Smithsonian Institution, Washington, DC 20013-7012, USA \\ cLaboratório de Diversidade de Morcegos, Instituto de Biologia, \\ Universidade Federal Rural do Rio de Janeiro - UFRRJ, \\ CP 74507, CEP 23890-000, Seropédica, RJ, Brazil \\ ${ }^{\mathrm{d} C}$ Conservation International, Center for Applied Biodiversity Science, \\ 2011 Crystal Drive, Suite 500, Arlington, VA 22202, USA \\ ePrograma de Pós-Graduação em Biodiversidade Tropical, Campus Universitário Marco Zero do Equador, \\ Universidade Federal do Amapá - UNIFAP, \\ Rod. Juscelino Kubitschek de Oliveira, Km 2, Zerão, CEP 68902-280, Macapá, AP, Brazil \\ *e-mail: monik.bats@gmail.com \\ Received June 2, 2008 - Accepted August 6, 2008 - Distributed November 30, 2009
}

(With 2 figures)

\begin{abstract}
In Brazil, restingas are under severe human-induced impacts resulting in habitat degradation and loss and remain one of the less frequently studied ecosystems. The main objectives of the present study are to describe the bat community in a restinga in Paulo Cesar Vinha State Park, Guarapari municipality, state of Espírito Santo, southeastern Brazil. Fieldwork was conducted twice a month from August 2004 to September 2005. A total sampling effort of $40,300 \mathrm{~m}^{2} / \mathrm{h}$, represents the largest sampling effort for sampling bats in restingas to date. Bats were sampled in five different vegetational types in the area. Captured bats were processed recording information on species, sex, age, forearm length and weight. Shannon Diversity and Jaccard indexes were used to analyse diversity and similarity among habitats in the Park. A total of 554 captures belonging to 14 species and two families were obtained. Noctilio leporinus was recorded through direct observation and an ultra-sound detector also registered the presence of individuals from the family Molossidae, without being possible to distinguish it at specific level. Frugivores were the most representative guild. Richness was higher in Clusia shrubs (11 species) and Caraís lagoon (10 species). Shannon diversity index was estimated at $H^{\prime}=1.43$ for the overall sample, with Caraís lagoon representing the most diverse habitat $\left(H^{\prime}=1.60\right)$. The greater similarity $(\mathrm{J}=0.714)$ was observed for the two areas under high human influence.
\end{abstract}

Keywords: Chiroptera, community ecology, diversity, restinga.

\section{Estrutura de comunidade de morcegos numa área protegida de restinga no Sudeste do Brasil}

\section{Resumo}

No Brasil, as restingas sofrem severos impactos humanos que resultam em perda e degradação de habitat. Além disso, constituem um dos ecossistemas menos estudados. Os principais objetivos deste estudo foram descrever uma parcela da quirópterofauna do Parque Estadual Paulo Cesar Vinha, município de Guarapari, Estado do Espírito Santo, e descrever a estrutura de comunidade de morcegos nessa área de restinga, no Sudeste do Brasil. O trabalho de campo foi realizado duas vezes por mês, de agosto de 2004 a setembro de 2005. O esforço de amostragem total foi de $40.300 \mathrm{~m}^{2} / \mathrm{h}$, que representa o maior esforço de captura para morcegos em restingas até o momento. Os morcegos foram capturados em diferentes tipos de vegetação e tiveram as informações de espécie, sexo, idade, comprimento do antebraço e peso anotadas. Os índices de diversidade de Shannon e Jaccard foram utilizados para analisar a diversidade e a similaridade entre os habitats. Foram obtidas 554 capturas representando 14 espécies e duas famílias. 
Noctilio leporinus foi registrado através de observação direta. Com o uso de um detector de ultrassons, registrou-se a presença de indivíduos da família Molossidae, não sendo possível a identificação da espécie. A riqueza foi maior no ambiente de Clusia (11 espécies) e na lagoa de Caraís (10 espécies). O índice de diversidade de Shannon foi estimado em H'=1,43 na área total amostrada, com a lagoa de Caraís, representando o habitat mais diverso $\left(H^{\prime}=1,60\right)$. A maior similaridade $(\mathrm{J}=0,714)$ foi observada entre as duas áreas sob maior influência antrópica. Um aumento no número de pesquisas em áreas de restinga é importante para garantir melhores medidas de conservação para esse ecossistema.

Palavras-chave: Chiroptera, diversidade, ecologia de comunidades, restinga.

\section{Introduction}

The Atlantic Forest is one of the world's most threatened and biodiverse biomes, being listed among the 34 biodiversity hotspots (Myers et al., 2000; Mittermeier et al., 2005). Historically, the coastal region of Brazil has been occupied by most of the country's population and it has been the most exploited region (Galindo-Leal and Câmara, 2003; Rocha et al., 2003; 2005; Dean, 2004). As a consequence, coastal ecosystems like restinga habitats (coastal sand dune habitats), are particularly threatened by human-induced habitat loss and fragmentation (Rocha and Bergallo, 1997; Rocha et al., 2003; 2005). Even though there is still no detailed quantification of restinga remnants, a significant amount of this ecosystem is lost yearly due to urbanisation (SOS Mata Atlântica and INPE, 2001; Rocha et al., 2007).

The restingas remain one of the less known and studied ecosystems within the Atlantic Forest (Rocha et al., 2003; 2004a; 2005). For the great majority of the restingas, there is an astounding lack of even the most basic information, like the species composition of terrestrial vertebrates (Rocha et al., 2003; 2005). Surprisingly, restingas remain one of the least-known environments, not only in biodiversity, but also regarding the present conservation status of their remnants, even though they are located in the highest human density zone in Brazil (Rocha, 2000; Rocha et al., 2005). Most of the studies in restingas regarding terrestrial vertebrates deal with reptiles (e.g. Rocha, 2000; Rocha et al., 2004b), amphibians (e.g. Carvalho e Silva et al., 2000; Izeckshon and Carvalho e Silva, 2001; Van Sluys et al., 2004), birds (e.g. Gonzaga et al., 2000; Alves et al., 2004) and small mammals (rodents and marsupials) (Cerqueira et al., 1990; 2000; Bergallo et al., 2004). Given the current high degree of destruction under which restingas are subject to (Rocha et al., 2007), one can imagine a scenario in which a great portion of these habitats are being eradicated without us having at least the knowledge even on the simple species composition and of the eventual presence of endemic and threatened species in such areas. This is particularly true and worrisome for bats.

There are a total of 512,434.83 ha of protected areas in the central corridors of the Atlantic Forest that encompass the restinga ecosystem (Rocha et al., 2003). The state of Espírito Santo has five protected areas that have restingas within their borders. These protected areas total more than 25,000 ha of restinga habitat protected in Espírito Santo, $22 \%$ of which are under strict protec- tion (Rocha et al., 2003). Nonetheless, the total amount of scientific information in these areas is still relatively restricted when compared to other ecosystems (Rocha et al. 2003). Setiba is one of the best studied restingas in Brazil (Rocha et al., 2003; 2005). A study evaluating 10 restingas in southeastern Brazil concluded that Setiba has an intermediate level of disturbance and a high level of vertebrate species richness (Rocha et al., 2003). The same study observed a negative relationship between human disturbance and vertebrate richness, stressing the importance of preserving this ecosystem in the face of anthropogenic threats (Rocha et al., 2003).

The main objectives of the present study are: 1) to inventory the bat species occuring in the Paulo Cesar Vinha State Park, 2) to compare species richness, abundance and diversity in five different restinga habitats within the Paulo Cesar Vinha State Park.

\section{Material and Methods}

\subsection{Study area}

Paulo Cesar Vinha State Park (20 32' 02'”$20^{\circ} 37^{\prime} 50^{\prime \prime} \mathrm{S}$ and $\left.40^{\circ} 22^{\prime} 433^{\prime}-40^{\circ} 25^{\prime} 59^{\prime \prime} \mathrm{W}\right)$, Guarapari municipality, state of Espírito Santo, southeastern Brazil, covers an area of 1,500 ha in southeastern Brazil (IPEMA, 2005). Its high plant diversity (Peixoto and Silva, 1997; Thomaz and Monteiro, 1997; Assis et al., 2004) contributes to the occurrence of a rich fauna (Pereira, 1990; Rocha et al., 2003). The climate of the region is tropical, with mean annual temperature of $23.3^{\circ} \mathrm{C}$ and mean annual rainfall of 1,307 mm (Fabris and César, 1996). Paulo Cesar Vinha State Park borders one of the main roads in southeastern Brazil (BR060, also known as Rodovia do Sol). The restinga of Setiba is listed as a priority area with high biological importance for the preservation of the Atlantic Forest biodiversity (CI Brasil, 2000). Paulo Cesar Vinha State Park's restinga ecosystem is comprised by different habitats: coastal lagoons, Clusia formations, restinga forest, and beaches (Cogliatti-Carvalho et al., 2000; Rocha et al., 2003). It also has two areas under human influence: the park's visitor centre (with buildings and exotic plants) and the trail used by visitors to access the beach. The park has three coastal lagoons (Feia, Vermelha and Caraís lagoons) and Caraís lagoon is the only one that is permanently connected to the sea and it has mangroves on one of its shores (IPEMA, 2005). 


\subsection{Data sampling and analysis}

Sampling sessions were conducted twice a month from August 2004 to October 2005. In each sampling session, we used from 8 to 10 mist-nets, that remained open for six hours consecutively since sunset and were checked every 20 minutes. We captured bats in five different habitats within Paulo Cesar Vinha State Park: 1) visitors centre; 2) main trail; 3) Clusia shrubs; 4) restinga forest, and 5) Caraís lagoon. Sampling effort was calculated following Straube and Bianconi (2002). Captured animals were measured (forearm length), weighed, sexed, and had their reproductive condition recorded. The species and location of capture were also recorded, and the bats kept in individual cotton bags until the end of the sampling session, when they were released at the same point where they were captured. Species richness and relative abundance were estimated for each habitat and for the entire sample (the whole park). Diversity was estimated using Shannon's index (Ludwig and Reynolds, 1988). Jaccard's index was used to calculate similarity between the park's habitats (Ludwig and Reynolds, 1988). The captured species were also classified into feeding guilds (adapted from Kalko et al., 1996): 1) insectivore, 2) carnivore, 3) piscivore, 4) sanguivore, 5) frugivore, 6) nectarivore and 7) omnivore. An ultrasound detector was used opportunistically during fieldwork, and visual observations were also made during the fieldwork sessions.

\section{Results}

We attained a total sampling effort of $40,300 \mathrm{~m}^{2} / \mathrm{h}$, and obtained a total of 554 captures, with a success of capture of 0.013 captures $/ \mathrm{m}^{2} / \mathrm{h}$. We captured 14 species from two families (Phyllostomidae and Vespertilionidae) (Table 1). Noctilio leporinus (Noctilionidae) was registered through direct observation at Caraís lagoon and by one dead individual encountered after colliding with a car at BR060. Molossidae bats were recorded using an ultra-sound device (Petersson 240), but they could not be identified to species level. At least two species are common in southeastern Brazil: Molossus molossus and Molossus rufus. The collector's curve suggested that more bat species should be recorded, if additional sampling effort were conducted at Paulo Cesar Vinha State Park (Figure 1).

The habitats having higher bat richness were Caraís lagoon and Clusia shrubs (Table 1). Carollia perspicillata, Artibeus lituratus, Artibeus cinereus and Glossophaga soricina were captured in all five habitats sampled (Table 1). Uroderma magnirostrum, Chiroderma doriae and Desmodus rotundus were captured only in the Clusia shrubs, and Phyllostomus hastatus and Anoura geoffroyi only at Caraís lagoon (Table 1). Shannon's diversity index for Paulo Cesar Vinha State Park was $H^{\prime}=1.43$. The diversity values for each habitat were: visitors centre $H^{\prime}=1.13$, main trail $H^{\prime}=1.26$, restinga forest $\mathrm{H}^{\prime}=0.886$, Caraís lagoon $\mathrm{H}^{\prime}=1.60$, and Clusia shrubs $H^{\prime}=1.56$. The visitors centre and the main trail were the most similar habitats $(\mathrm{J}=0.714)$, whereas the main trail and the Clusia shrubs were the least similar ones $(\mathrm{J}=0.400)$ (Table 2$)$.

The analysis of feeding guilds showed that frugivores (Artibeus lituratus, A. cinereus, Carollia perspicillata, Chiroderma villosum, C. doriae, Platyrrhinus lineatus, Pygoderma bilabiatum and Uroderma magnirostrum)

Table 1. Species richness and relative abundance of bats captured in the five habitats within Paulo Cesar Vinha State Park (PEPCV), Guarapari municipality, state of Espírito Santo, and the totals for the overall area of the park.

\begin{tabular}{llrrrrrr}
\hline \multicolumn{1}{c}{ Species } & Guild & \multicolumn{3}{c}{ Habitats } & \multicolumn{2}{c}{$\begin{array}{c}\text { PEPCV } \\
\text { (Total) }\end{array}$} \\
\cline { 3 - 7 } & & $\begin{array}{c}\text { Visitors } \\
\text { center }\end{array}$ & $\begin{array}{c}\text { Main } \\
\text { trail }\end{array}$ & $\begin{array}{c}\text { Clusia } \\
\text { shrubs }\end{array}$ & $\begin{array}{c}\text { Restinga } \\
\text { forest }\end{array}$ & $\begin{array}{c}\text { Caraís } \\
\text { lagoon }\end{array}$ \\
\hline Desmodus rotundus & Sanguivore & - & - & 2 & - & - & 2 \\
Anoura geoffroyi & Nectarivore & - & - & - & - & 1 & 1 \\
Glossophaga soricina & Nectarivore & 5 & 5 & 17 & 1 & 35 & 63 \\
Carollia perspicillata & Frugivore & 62 & 49 & 28 & 31 & 21 & 191 \\
Artibeus cinereus & Frugivore & 5 & 8 & 6 & 6 & 2 & 27 \\
Artibeus lituratus & Frugivore & 30 & 20 & 63 & 88 & 26 & 227 \\
Chiroderma doriae & Frugivore & - & - & 1 & - & - & 1 \\
Chiroderma villosum & Frugivore & - & - & 2 & 2 & - & 4 \\
Platyrrhinus lineatus & Frugivore & 3 & - & 5 & - & 3 & 11 \\
Pygoderma bilabiatum & Frugivore & - & - & 2 & - & 1 & 3 \\
Uroderma magnirostrum & Frugivore & - & - & 2 & - & - & 2 \\
Phyllostomus discolor & Omnivore & 1 & - & 2 & 1 & 6 & 10 \\
Phyllostomus hastatus & Omnivore & - & - & - & - & 1 & 1 \\
Myotis nigricans & Insectivore & 1 & 9 & - & - & 1 & 11 \\
\hline Total number of captures & & 107 & 91 & 130 & 129 & 97 & 554 \\
Total number of species & & 7 & 5 & 11 & 6 & 10 & 14 \\
\hline
\end{tabular}




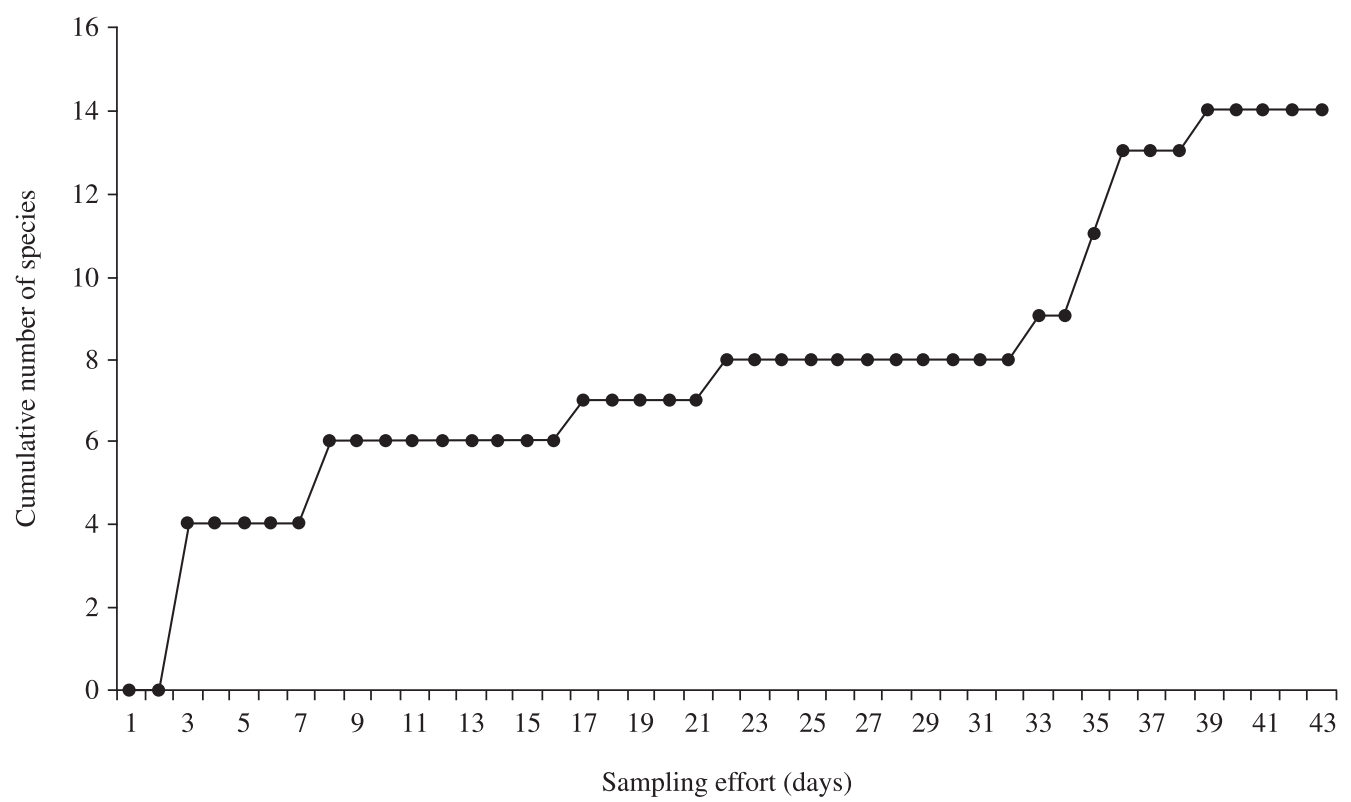

Figure 1. Cumulative numbers of bat species captured (collector's curve) at Paulo Cesar Vinha State Park, Guarapari municipality, State of Espírito Santo.

Table 2. Jaccard's similarity index (J) comparing each pair of habitats among the five sampled habitats at Paulo Cesar Vinha State Park, Guarapari municipality, State of Espírito Santo.

\begin{tabular}{lccccc}
\hline \multicolumn{1}{c}{ Habitats } & Visitors centre & Main trail & Clusia shrubs & Restinga forest & Caraís lagoon \\
\hline Visitors centre & - & - & - & - & - \\
Main trail & 0.714 & - & - & - & - \\
Clusia shrubs & 0.454 & 0.400 & - & - & - \\
Restinga forest & 0.625 & 0.571 & 0.545 & - & - \\
Caraís lagoon & 0.700 & 0.500 & 0.538 & 0.454 & - \\
\hline
\end{tabular}

represent the majority of species $(57 \%)$ and the majority of captures (84\%) (Table 1). Nectarivores were represented by Glossophaga soricina and Anoura geoffroyi (Table 1). Two species of omnivores were recorded: Phyllostomus discolor and P. hastatus (Table 1). The insectivores were represented by the species Myotis nigricans and Molossus sp. (Table 1). Sanguivores and piscivores were represented by only one species each, Desmodus rotundus and Noctilio leporinus (Table 1).

\section{Discussion}

To date, only 12 restinga sites have studies focusing on bats: Restinga da Ilha de Cabo Frio (Fernandez et al., 1988); Restinga de Ilha Grande (Fernandez et al., 1988); Restinga da Barra de Maricá (Cerqueira et al., 1990); Restinga de Saquarema (Esbérard, 2004); Chico Mendes State Park (Esbérard, 2004); Restinga da Praia dos Ossos (Esbérard, 2004); Arruda Câmara Municipal Park (Marques, 2000); Restinga de Macaé (Esbérard, 2004); Restinga de Jurubatiba National Park (Mangolin, 2005); Restinga de Guriri (Moreno et al., 2000); Ilha do Cardoso
State Park (Fazzolari-Correa, 1995); Rio da Onça State Park (Fogaça, 2003; Dala Rosa, 2004) (Figure 2).

The present study represents the largest sampling effort for bats in the restinga ecosystem. The diversity index of Paulo Cesar Vinha State Park $\left(H^{\prime}=1.43\right)$ is relatively high when compared to other restingas studied: Ilha do Cardoso (H'= 1.41; Fazzolari-Corrêa, 1995), Praia dos Ossos (H' = 1.21; Dala Rosa, 2004), Arruda Câmara Park $\left(H^{\prime}=0.68\right.$; Marques, 2000).

The bat species richness of Paulo Cesar Vinha State Park (15 species) is also among the highest among restinga sites. Restinga de Jurubatiba National Park is the restinga with highest bat richness recorded (17 species; Mangolin, 2005) and the restingas with lower bat richness are Maricá, Saquarema and Cabo Frio (2 species in each one; Fernandez et al., 1988; Cerqueira et al., 1990; Esbérard, unpublished data), although it is important to consider differences among studies in sampling effort and period of the year sampled. However, these restingas with lower richness were also those with smaller sampling effort and they probably house more species than 


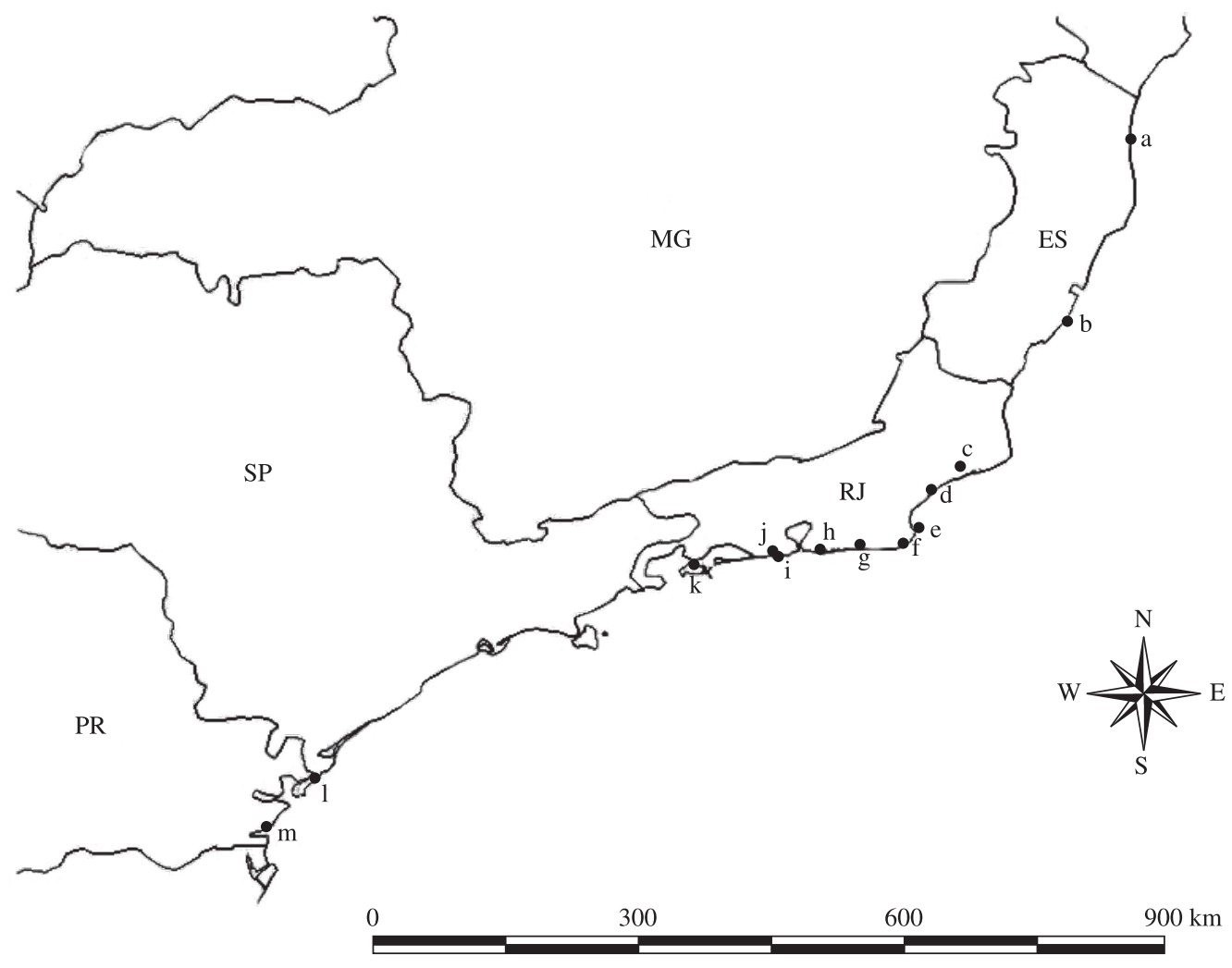

Figure 2. Restinga areas that have already been surveyed for bats: a) Restinga de Guriri (Moreno et al., 2000); b) Paulo Cesar Vinha State Park (this study); c) Restinga de Jurubatiba National Park (Mangolin, 2005); d) Restinga de Macaé (Esbérard, 2004); e) Restinga da Praia dos Ossos (Esbérard, 2004); f) Restinga da Ilha de Cabo Frio (Fernandez et al., 1988); g) Restinga de Saquarema (Esbérard, 2004); h) Restinga da Barra de Maricá (Cerqueira et al., 1990); i) Chico Mendes State Park (Esbérard, 2004); j) Arruda Câmara Municipal Park (Marques, 2000); k) Restinga de Ilha Grande (Fernandez et al., 1988); 1) Ilha do Cardoso State Park (Fazzolari-Correa, 1995); and m) Rio da Onça State Park (Fogaça, 2003; Dala Rosa, 2004).

currently recorded. Bergallo et al. (2003) suggest that 1,000 captures is the sample size needed to properly inventory Atlantic Forest sites. Taking this estimative into account it is clear that all restingas sampled so far are considerably under-sampled. Even though the present study represents the largest mist-netting effort in restingas, the low success of capture for bats in this ecosystem suggests that bats are quite under-sampled and consequently an important gap in the knowledge of restinga biodiversity persists.

There were differences in species composition in the sampled habitats. Habitats under higher human influence (visitors centre and main trail) had lower diversity values. Carollia perspicillata was captured in all habitats, and it represented more than half of the captures at the visitor's centre and at the main trail. P. lineatus, A. lituratus and $G$. soricina are cited as generalist species able to adapt themselves to human disturbance (Bredt and Uieda, 1996). Regarding guild structure, our results seem to corroborate the restricted information available (e.g. Dala Rosa 2004), with frugivores being the most representative guild. The higher representation of frugivores may be a true result, but it may also reflect a bias in the sampling method used (mist-nets) (Arita, 1993; Pedro and Taddei, 1997). Artibeus lituratus was the most common species at Paulo Cesar Vinha State Park, and this is in accordance with observations from other restinga sites (e.g. Fazzolari-Correa 1995; Fogaça 2003; Dala Rosa 2004).

The restingas are recognised as important areas for biodiversity conservation in Brazil (CI Brasil et al., 2000; Rocha et al., 2003; 2005). However, there are still relatively few protected areas comprising restingas (e.g. Jurubatiba National Park), covering a small representative area of this ecosystem, even though this environment is under severe threat. There is urgent need for a better representativeness in the network of protected areas in the Atlantic Forest, including restingas (Rocha et al., 2007). In order to achieve this goal, a better knowledge of the species that occur in the restinga, and their ecology, is needed, as exemplified by indications that bats are still severely understudied in this ecosystem. 


\section{References}

ALVES, MAS., STORNI, A., ALMEIDA, EM., GOMES, VSM., OLIVEIRA, CHP., MARQUES, RV. and VECCHI, MB. 2004. A comunidade de aves na restinga de Jurubatiba. In ROCHA, CFD., ESTEVES, FA. and SCARANO, FR. Pesquisas de longa duração na restinga de Jurubatiba: ecologia, história natural e conservação. São Carlos: Rima. p. 199-214.

ARITA, HT. 1993. Rarity in neotropical bats: correlations with phylogeny, diet, and body mass. Ecological Applications, vol. 3, no. 3 , p. 506-517.

ASSIS, AM., PEREIRA, OJ. and THOMAZ, LD. 2004. Fitossociologia de uma floresta de restinga no Parque Estadual Paulo César Vinha, Setiba, município de Guarapari (ES). Revista Brasileira de Botânica, vol. 27, no. 2, p. 349-361.

BERGALLO, HG. et al. 2003. Bat species richness in atlantic forest: what is the minimum sampling effort? Biotropica, vol. 35 , no. 2 , p. $278-288$.

2004. Os mamíferos da restinga de Jurubatiba. In ROCHA, CFD., ESTEVES, FA. and SCARANO FR. Pesquisas de longa duração na restinga de Jurubatiba: ecologia, história natural e conservação. São Carlos: Rima. p. 215-230.

BREDT, A. and UIEDA, W. 1996. Bats from urban and rural environments of the Distrito Federal, Mid-Western Brazil. Chiroptera Neotropical, vol. 2, no. 2, p. 54-57.

CARVALHO, E., SILVA, SP., IZECKSOHN, E. and SILVA, AMPTC. 2000. Diversidade e ecologia de anfibios em restingas do sudeste brasileiro. In ESTEVES, FA. and LACERDA, LD. Ecologia de restingas e lagoas costeiras. Macaé: NUPEM/ UFRJ. p. 89-97.

CERQUEIRA, R. 2000. Biogeografia das restingas. In ESTEVES, FA. and LACERDA, LD. Ecologia de restingas $e$ lagoas costeiras. Macaé: NUPEM/UFRJ. p 65-75.

CERQUEIRA, R., FERNANDEZ, FAS. and NUNES, MFQS. 1990. Mamíferos da restinga da Barra de Maricá. Papéis Avulsos de Zoologia, vol. 37, no. 9, p. 141-157.

CONSERVATION INTERNATIONAL DO BRASIL - CI BRASIL. 2000. Avaliação e ações prioritárias para a conservação da biodiversidade da Mata Atlântica e campos sulinos. Brasília: CI Brasil. 40 p.

COGLIATTI-CARVAlHO, L., FREITAS, AFN., PESSÔA, TCR. and ROCHA, CFD. 2000. Parâmetros da ecologia de comunidades de Bromeliaceae em cinco zonas de vegetação da restinga de Setiba, ES. In ACIESP. Anais do V Simpósio de Ecossistemas Brasileiros. Vitória: ACIESP. p. 20-30.

DALA ROSA, S. 2004. Morcegos (Chiroptera, Mammalia) de um remanescente de restinga, Estado do Paraná, Brasil: ecologia da comunidade e dispersão de sementes. Curitiba: UFPR. [Dissertação de Mestrado].

DEAN, W. 2004. A ferro e fogo: a história e a devastação da Mata Atlântica brasileira. São Paulo: Companhia das Letras. ESBÉRARD, CEL. 2004. Morcegos no estado do Rio de Janeiro. Rio de Janeiro: UERJ. [Tese de Doutorado].

FABRIS, LC. and CÉSAR, O. 1996. Estudos florísticos em uma mata litorânea no sul do estado do Espírito Santo. Boletim do Museu de Biologia - Prof. Mello Leitão, vol. 5, p. 15-46.
FAZZOLARI-CORRÊA, S. 1995. Aspectos sistemáticos, ecológicos e reprodutivos de morcegos na Mata Atlântica. São Paulo: USP. [Tese de Doutorado].

FERNANDEZ, FAS., CERQUEIRA, R. and TRIBE, CJ. 1988. On the mammals collected on coastal islands of Rio de Janeiro state, Brazil. Mammalia, vol. 52, no. 2, p. 219-224.

FOGAÇA, FNO. 2003. Chiroptera (Mammalia) do parque florestal Rio da Onça (Matinhos, PR). Curitiba: UFPR. [Dissertação de Mestrado].

GALINDO-LEAL, C. and CÂMARA, IG. 2003. Atlantic Forest hotspot status: an overview. In GALINDO-LEAL, C. and CÂMARA, IG. The atlantic forest of south America: biodiversity status, threats and outlook. Washington: Island Press. p. 3-11.

GONZAGA, LP., CASTIGLIONI, GDA. and REIS, HBR. 2000. Avifauna das restingas do sudeste: estado do conhecimento e potencial para futuros estudos. In ESTEVES, FA. and LACERDA, LD. Ecologia de restingas e lagoas costeiras. Macaé: NUPEM/UFRJ. p. 179-188.

Instituto de Permacultura e Ecovilas da Mata Atlântica IPEMA. 2005. Conservação da Mata Atlântica no estado do Espírito Santo: cobertura florestal e unidades de conservação. Vitória: IPEMA. 152 p.

IZECKSOHN, E. and CARVALHO E SILVA, SP. 2001. Anfibios do municipio do Rio de Janeiro. Rio de Janeiro: UFRJ. 144 p.

KALKO, EKV., HANDLEY, CO. and HANDLEY, D. 1996. Organization, diversity, and long-term dynamics of a Neotropical bat community. In CODY, M. and SMALLWOOD, J. Long-term studies in vertebrate communities. Los Angeles: Academic Press. p. 503-553.

LUDWIG, JA. and REYNOLDS, JF. 1988. Statistical ecology: a primer on methods and computing. New York: John Wiley and Sons.

MANGOLIN, R. 2005. Quirópteros (Mammalia: Chiroptera) do Parque Nacional da Restinga de Jurubatiba, Rio de Janeiro, Brasil. Rio de Janeiro: UERJ. [Dissertação de Mestrado].

MARQUES, AM. 2000. Aspectos ecológicos dos quirópteros de uma área de restinga, Parque Arruda Câmara (Bosque da Barra), Rio de Janeiro, RJ. Seropédica: UFRRJ. [Dissertação de Mestrado].

MITTERMEIER, RA., GIL, PR., HOFFMAN, M., PILGRIM, J., BROOKS, T., MITTERMEIER, CG., LAMOREUX, J., FONSECA, GAB., SELIGMANN, PA., FORD, H. 2005. Hotspots revisited: earth's biologically richest and most endangered terrestrial ecoregions. Mexico: CEMEX. 392 p.

MORENO, MR., MARINATO, CS., SILVE, VJM., PARIZ, S. and NASCIMENTO, MT. 2000. Morcegos da restinga da ilha de Guririr, São Mateus, Espírito Santo e a dispersão de sementes de Solanaceae e Cactaceae. In Anais do V Simpósio de ecossistemas brasileiros. Vitória: ACIESP. p. 31-38.

MYERS, N., MITTERMEIER, RA., MITTERMEIER, CG., FONSECA, GAB and KENT, J. 2000. Biodiversity hotspots for conservation priorities. Nature, vol. 403, no. 6772, p. 853-858.

PEDRO, WA. and TADDEI, VA. 1997. Taxonomic assemblage of bats from Panga Reserve, southeastern Brazil: abundance, patterns and trophic relations in the Phyllostomidae (Chiroptera). Boletim do Museu de Biologia - Prof. Mello Leitão, vol. 6, p. 3-21. 
PEIXOTO, AL. and SILVA, IM. 1997. Tabuleiro forests of northern Espirito Santo, south-eastern Brazil. In DAVIS, SD. Centres of plant diversity: a guide and strategy for their conservation. Cambrige: IUCN. p. 369-372.

PEREIRA, OJ. 1990. Caracterização fitofisionômica da restinga de Setiba - Guarapari/ES. In WATANABE, S. Anais do II Simpósio de Ecossistemas da Costa Sul e Sudeste Brasileira. São Paulo: ACIESP. p. 207-219

ROCHA, CFD. 2000. Biogeografia de répteis de restinga: distribuição, ocorrência e endemismos. In ESTEVES, FA. and LACERDA, LD. Ecologia de restingas e lagoas costeiras. Macaé: NUPEM/UFRJ. p. 99-116

ROCHA, CFD. and BERGALLO, HG. 1997. Intercommunity variation in the distribution and abundance of dominant lizard species in restinga habitats. Ciência e Cultura Journal of the Brazilian Association for the Advancement of Science, vol. 49, no. 4, p. 269-274.

ROCHA, CFD., BERGALlO, HG., ALVES, MAS. and Van SLUYS, M. 2003. A biodiversidade nos grandes remanescentes florestais do estado do Rio de Janeiro e nas restingas da Mata Atlântica. São Carlos: Rima. 146 p.

ROCHA, CFD., BERGALlO, HG., ALVES, MAS. and Van SLUYS, M. 2004. A restinga de Jurubatiba e a conservação dos ambientes de restinga do Estado do Rio de Janeiro. In ROCHA, CFD., ESTEVES, FA. and SCARANO, FR. Pesquisas de longa duração na restinga de Jurubatiba: ecologia, história natural e conservação. São Carlos: Rima. p. 341-352

ROCHA, CFD. et al. 2004. A comunidade dos repteis da restinga de Jurubatiba. In ROCHA, CFD., ESTEVES, FA. and SCARANO, FR. Pesquisas de longa duração na restinga de Jurubatiba: ecologia, história natural e conservação. São Carlos: Rima. p. 179-198.

ROCHA, CFD., Van SLUYS, M., BERGALLO, HG. and ALVES, MAS. 2005. Endemicand threatened tetrapods in the restingas of the biodiversity corridors of Serra do Mar and of the Central da Mata Atlântica in eastern Brazil. Revista Brasileira de Biologia = Brazilian Journal of Biology, vol. 65, no. 1, p. $159-168$.

ROCHA, CFD., BERGALLO, HG., Van SLUYS, M., ALVES, MAS. and JAMEL, CE. 2007. The remnants of restinga habitats in the Brazilian Atlantic Forest of Rio de Janeiro State, Brazil: habitat loss and risk of disappearance. Revista Brasileira de Biologia = Brazilian Journal of Biology, vol. 67, no. 2, p. $263-273$.

SOS MATA ATLÂNTICA and INPE. 2001. Atlas dos remanescentes florestais da mata Atlântica. São Paulo: SOS Mata Atlântica.

STRAUBE, FC. and BIANCONI, GV. 2002. Sobre a grandeza e a unidade utilizada para estimar esforço de captura com utilização de redes de neblina. Chiroptera Neotropical, vol. 8, no. 1-2, p. 150-152.

THOMAZ, LD. and MONTEIRO, R. 1997. Composição florística da Mata Atlântica de encosta da Estação Biológica de Santa Lúcia, município de Santa Teresa, ES. Boletim do Museu de Biologia - Prof. Mello Leitão, vol. 7, p. 1-48.

Van SLUYS, M., ROCHA, CFD., HATANO, FH., BOQUIMPANI-FREITAS, L. and MARRA, RV. 2004. Anfibios da restinga de Jurubatiba: composição e história natural. In ROCHA, CFD., ESTEVES, FA. and SCARANO FR. Pesquisas de longa duração na restinga de Jurubatiba: ecologia, história natural e conservação. São Carlos: Rima. p. 165-178 